JADWIGA GAŁKA

Uniwersytet Jagielloński, Kraków, Polska

SŁAWOMIR DOROCKI

Uniwersytet Pedagogiczny, Kraków, Polska

\title{
Rola emigracji klasy kreatywnej w przemianach gospodarki innowacyjnej w Polsce
}

\author{
The Role of Creative Class Emigration \\ in the Changes of an Innovation Economy in Poland
}

\begin{abstract}
Streszczenie: Jednym z mierników poziomu rozwoju ekonomicznego regionów i krajów jest innowacyjność jego gospodarki. Powszechnie przyjmuje się, że współcześnie głównym czynnikiem rozwoju gospodarki opartej na wiedzy jest wysoki poziom kwalifikacji kapitału ludzkiego. W związku z dużym zapotrzebowaniem na wykształcone kadry oraz nasilającym się procesem globalizacji - osłabiającym bariery migracyjne, we współczesnym świecie coraz silniej uwidacznia się tzw. proces drenażu mózgów. Proces ten obejmuje osoby dobrze i bardzo dobrze wykształcone oraz profesjonalistów, którzy przyciągani są przez wysoko rozwinięte regiony i kraje. Ta selektywna emigracja ma zatem niekorzystny wpływ na potencjał innowacyjny obszarów biedniejszych. Celem niniejszego artykułu jest próba odpowiedzi na pytania, czy wzrost migracji międzynarodowych z Polski po jej akcesji do Unii Europejskiej spowodował negatywną selekcję kadr pracowniczych w Polsce oraz jak ten proces wpłynął na poziom innowacyjności w skali lokalnej? W pracy wykorzystano dane statystyczne GUS, dotyczące skali i kierunków wyjazdów zagranicznych Polaków po 1 maja 2004 roku oraz dane ankietowe zebrane wśród polskich imigrantów w Londynie w 2010 roku. Z badań wynika, że akcesja Polski do Unii Europejskiej zainicjowała negatywne zmiany struktury zasobów ludzkich, zwłaszcza w dużych miastach kraju, tj. w Warszawie, Krakowie i Poznaniu.
\end{abstract}

Abstract: The innovativeness of an economy is one of the indicators of national and regional economic
development. It is widely accepted that a major factor in the development of a knowledge-based econ-
omy is highly skilled human capital. Due to a high demand for an educated workforce and the intensi-
fying process of globalization, which undermines migration barriers, the process of ,brain drain” can
be increasingly observed in the modern world. This process includes educated and very well educated
individuals who are attracted by highly developed regions and countries. Therefore, this selective type
of migration has a negative impact on the innovative potential of poorer areas. The aim of this paper is
to show how international migration from Poland following the enlargement of the European Union af-
fected the quality of the job applicant pool in Poland. We also want to show how international migration
affects the level of innovation on a local scale. We used different sources of data to achieve our goals.
This included statistical data provided by the Central Statistical Office (Polish acronym: GUS) and 
survey data collected among Polish immigrants in London in 2010. Research has shown that, following Poland's entry into the European Union, changes in the quality of the job applicant pool are evident in large cities such as Warsaw, Kraków and Poznań.

Słowa kluczowe: drenaż mózgów; emigracja; klasa kreatywna; Londyn; Polska

Key words: brain drain; creative class; emigration; London; Poland

\section{WSTĘP}

Powszechnie przyjmuje się, że współcześnie w informacyjnej fazie rozwoju cywilizacyjnego zasadniczo zmienia się podstawowa baza ekonomiczna różnej skali układów przestrzennych (Borowiec i in., 2009). Rezultatem tych przemian jest przeobrażanie się struktury rynku pracy oraz coraz większe znaczenie jakości kapitału ludzkiego w kreowaniu rozwoju gospodarczego. Znaczenie kapitału ludzkiego jest szczególnie widoczne w procesach kształtowania gospodarki opartej na wiedzy różnej skali układów przestrzennych (Borowiec 2011; Borowiec, Dorocki, 2011). Klasa kreatywna stała się kluczowym czynnikiem wpływającym na możliwości zwiększenia innowacyjności i konkurencyjności układów krajowych, regionalnych i lokalnych (Stryjakiewicz, 2009; Krupa 2012; Mellander, Florida, 2012). Istotną rolę w kreowaniu rozwoju przypisuje się dziś wiedzy i umiejętnościom pracowników, które kształtowane są w procesie edukacji, zwłaszcza na poziomie wyższym (Borowiec 2008). Gospodarka oparta na wiedzy funkcjonuje głównie dzięki wykorzystaniu zasobów wiedzy oraz rozwoju technologii umożliwiającej szybki dostęp do informacji. Fundamentem jej rozwoju jest zatem potencjał do tworzenia i absorpcji innowacji, mających na celu modernizację gospodarki oraz wzrost jej produktywności i konkurencyjności (m.in. Goldberg, 2004; Goldberg i in., 2008; Chojnicki, Czyż, 2008; Dorocki, 2008; Zioło, 2008; Borowiec, 2010). Nauka i nowoczesna technologia, w tym zaplecze badawcze i kadry naukowe, stanowią zatem determinanty rozwoju społeczno-gospodarczego układów regionalnych i krajowych (Kilar, 2008). Szczególną rolę w rozwoju technologicznym różnych układów przestrzennych przypisuje się kadrom naukowym i specjalistom związanym z sektorem ICT oraz rozwijającym się sektorem biotechnologicznym i nanotechnologicznym (Miyamoto, 2003; Dorocki, Jastrzębski, 2011). Uznaje się zatem, że to głównie kapitał ludzki tych działów gospodarki wraz z jego otoczeniem (usługi i instytucje wspierające innowacyjność i transfer wiedzy) stanowią o rozwoju innowacyjnej gospodarki (Guastella, Oort, 2012). Inną ważną cechą charakteryzującą kadry innowacyjne jest ich deficyt na rynku pracy oraz długi czas i wysokie koszty potrzebne na ich wykształcenie. Skutkuje to dużymi dysproporcjami w ich przestrzennym rozmieszczeniu oraz mobilnością związaną z przyciąganiem ich przez najbardziej konkurencyjne regiony świata. Szczególnie negatywny skutek dla rozwoju gospodarczego regionów i krajów przynosi tzw. drenaż mózgów, odbywający się przez odpływ klasy kreatywnej. Proces negatywnej selekcji migracyjnej osłabia potencjał innowacyjny różnej skali układów przestrzennych, spowalniając ich rozwój, co w konsekwencji wpływa na osłabienie ich konkurencyjności (Rachwał, 2011). 
Z dotychczasowych badań z zakresu mobilności przestrzennej ludności wynika, że migracje zagraniczne bardzo często wywołują negatywne procesy w krajach wysyłających. Prowadzą bowiem do depopulacji regionów, utrwalają negatywny wzorzec pracy (głównie migracje sezonowe), negatywnie wpływają na poziom wykształcenia ludności i powodują drenaż mózgów. Tego typu zjawisko można było zaobserwować w niektórych krajach Środkowo-Wschodniej i Południowej Europy (Barteczko, 2006; Glytsos, 2006; Hryniewicz i in., 1992 1997; Ivakhnyuk, 2006; Parkhomenko, 2006). Z najnowszych badań wynika, że otwarcie granic po rozszerzeniu Unii Europejskiej w 2004 roku wpłynęło na wzrost emigracji wysokiej klasy specjalistów nie tylko z Polski, ale także z innych krajów w tej części Europy (Kaczmarczyk, Okólski, 2005; Kaczmarczyk, 2006). Niestety, wiedza na ten temat jest w dalszym ciągu zbyt uboga, zwłaszcza w układach regionalnych. Dlatego w tym artykule starano się szerzej zbadać to zagadnienie.

Celem niniejszego artykułu jest próba odpowiedzi na pytania: czy wzrost migracji międzynarodowych z Polski po jej akcesji do Unii Europejskiej spowodował negatywną selekcję kadr pracowniczych w Polsce oraz jak ten proces wpłynął na poziom innowacyjności w skali lokalnej?

W pracy wykorzystano różne źródła danych statystycznych i jakościowych. Wśród nich znalazły się dane Głównego Urzędu Statystycznego (GUS) o liczbie wymeldowań na pobyt stały. Drugim ważnym źródłem informacji były badania ankietowe, przeprowadzone w Londynie w 2010 roku. Łącznie zebrano 1348 kwestionariuszy, z których 1272 poddano dalszym analizom. Analizując poszczególne pytania, uwzględniono za każdym razem tylko ankiety ważne, tzn. te $\mathrm{z}$ odpowiedziami respondentów.

\section{CZynNiki OdPŁyWu LUdNOŚCI Z POLSKI W ŚWIETLE KONCEPCJI PUSH-PULL FACTORS}

Akcesja Polski do Unii Europejskiej spowodowała gwałtowny odpływ Polaków za granicę zarówno na pobyt stały, jak i czasowy. Wśród wielu teorii migracyjnych wyjaśniających mechanizmy migracji zarobkowych ludności można odnaleźć koncepcję push-pull factors, w ramach której analizuje się przyczyny migracji w kraju pochodzenia oraz czynniki przyciągające w kraju docelowej emigracji (Lee, 1966). Jednym z głównych czynników wypychających z Polski przed rozszerzeniem Unii Europejskiej było wysokie bezrobocie (w 2002 roku sięgało 21,2\%). Najwyższa stopa bezrobocia utrzymywała się w Polsce Zachodniej i Północnej, na terenach wysokiego udziału dawnego sektora państwowego w rolnictwie oraz na Kielecczyźnie i na terenie województwa kujawsko-pomorskiego (Gałka, 2012a). Innym problemem była nadwyżka siły roboczej na terenach wiejskich, zwłaszcza na obszarach należących do dawnego zaboru rosyjskiego. Przeprowadzony w 1996 roku Powszechny Spis Rolny ujawnił 800 tys. (tj. 20\%) osób zbędnych wśród pracujących wyłącznie lub głównie w gospodarstwie (Rosner, 2009). W kolejnych latach liczba ta zwiększała się. Powodem tej sytuacji było zmniejszenie zapotrzebowania na siłę roboczą w gospodarstwach ze względu na postęp techniczny, powolne zwiększanie się liczby miejsc pracy w miastach oraz zmiany demograficzne związane $\mathrm{z}$ wchodzeniem $\mathrm{w}$ wiek produkcyjny wyżu demograficznego $\mathrm{z}$ lat 80. XX wieku. 
Szansa na poprawę perspektyw życiowych pojawiła się w chwili akcesji Polski do Unii Europejskiej. Obok tradycyjnych kierunków zagranicznych wyjazdów Polaków (Francja, USA, Niemcy), pojawiły się nowe, takie jak Wielka Brytania i Irlandia, które przeżywały niespotykany wcześniej napływ imigrantów z Polski (Gałka, 2012b; Pollard i in., 2006).

\section{Skala emigraci z Polski na pobyt staly po ROZSZERZENIU Unit EuropejSKIEJ}

Niewątpliwie bogactwem każdego kraju są jego mieszkańcy. Niestety, akcesja Polski do Unii Europejskiej spowodowała odpływ tysięcy jej obywateli za granicę, z których część już nigdy do niej nie wróci. Tym samym obniżył się potencjał ludnościowy naszego kraju. Oficjalne statystyki dotyczące liczby emigrantów nie są w pełni wiarygodne, gdyż definicja emigranta przyjęta przez GUS pomija osoby, które nie dopełniły obowiązku zgłoszenia wyjazdu w odpowiednim urzędzie. Niemniej jednak dane te pozwalają na określenie pewnych trendów w tym zakresie.

Według danych GUS łącznie w latach 2004-2010 wyjechało z Polski na pobyt stały 189655 osób, co stanowiło 0,5\% ludności kraju. Największy odpływ zanotowano w 2006 roku, po czym od tego roku skala wyjazdów na pobyt stały z roku na rok się zmniejszała. Wynikało to z kilku powodów. Pierwszym z nich było wygasanie rezerw migracyjnych w kraju, drugim zmiana prawa podatkowego, które nakładało obowiązek odprowadzania należności w kraju pochodzenia oraz w kraju zarobkowania. Dopiero po jego zniesieniu część emigrantów zrezygnowała z zamiaru wymeldowania się z pobytu stałego (ryc. 1).

Warto dodać, że do 2008 roku w wyjazdach zagranicznych Polaków na pobyt stały dominowali mężczyźni, którzy, jak wiadomo, są bardziej skłonni do migracji na większe odległości (Ravenstein, 1885). Po czym od 2008 roku dysproporcje pomiędzy liczbą emigrujących kobiet i mężczyzn zaczęły się zmniejszać. W 2009 roku można było zaobserwować wzrost wymeldowań kobiet. Należy to łączyć z procesem zwanym łańcuchem migracyjnym, zgodnie z którym w pierwszej kolejności wyjeżdżają za granicę osoby najodważniejsze i najbardziej skłonne do ryzyka (czyli głównie mężczyźni), które po zapoznaniu się z warunkami życia i pracy w nowym kraju sprowadzają pozostałych członków rodziny, przyjaciół (kobiety z dziećmi) (tab. 1). To, niestety, świadczy o tym, że migracje Polaków przybierają formę trwałych migracji osiedleńczych. 


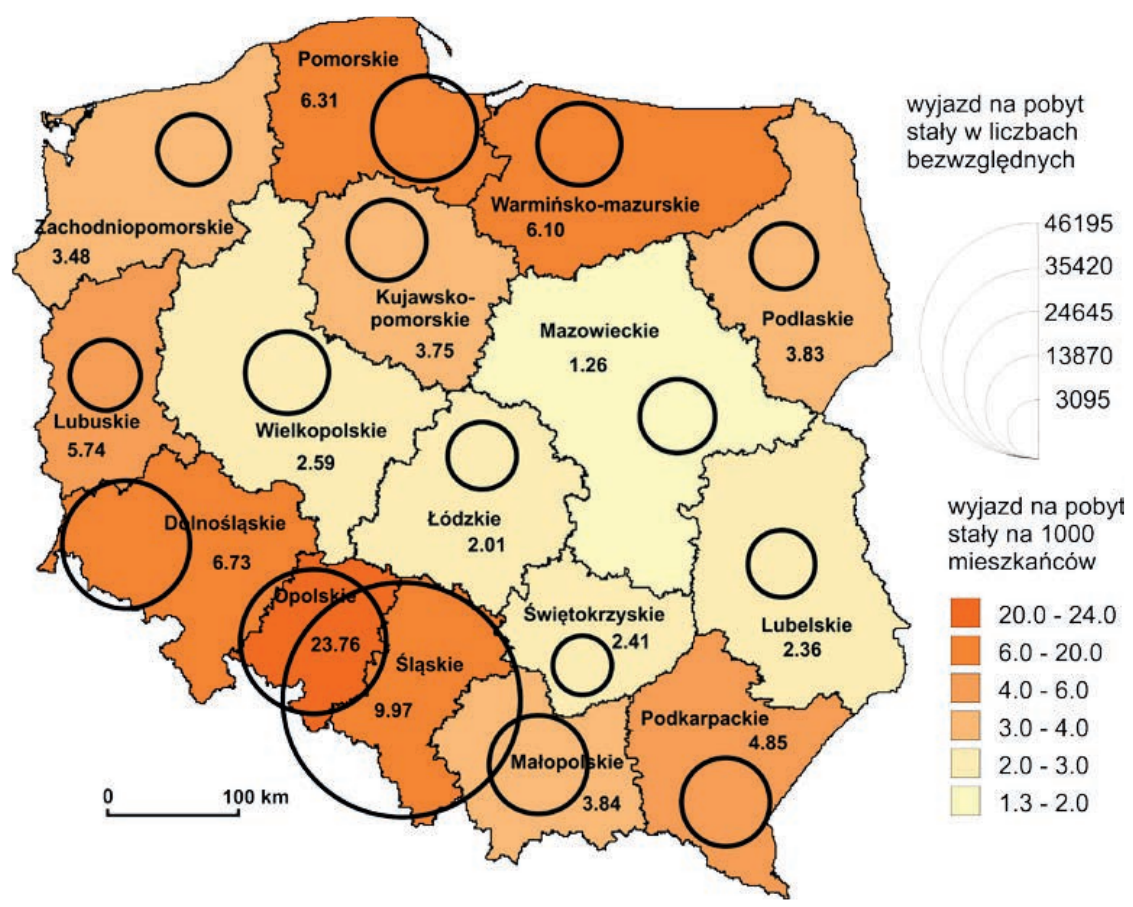

Ryc. 1. Wyjazdy na pobyt stały według województw w latach 2004-2010

Źródło: opracowanie własne na podstawie danych GUS

Analizując problem migracji klasy kreatywnej, należałoby się zastanowić, z których regionów wyjechało najwięcej osób. Z badań wynika, że łącznie w latach 2004-2010 najwięcej emigrantów pochodziło z województw o długich tradycjach migracyjnych oraz z terenów, które mocno ucierpiały wskutek restrukturyzacji gospodarki, tj.: śląskiego $(24,4 \%)$, opolskiego (12,7\%) oraz dolnośląskiego (10,4\%). Najmniej natomiast wyjechało z województw o małej liczbie ludności oraz z mocno zaawansowanymi procesami starzenia się ludności, tj.: świętokrzyskiego $(1,6 \%)$ i podlaskiego $(2,4 \%)$. Regiony te nie były więc na tyle atrakcyjne pod względem dobrze rozwiniętego i zróżnicowanego rynku pracy, aby zatrzymać młodą dobrze wykształconą kadrę pracowniczą na miejscu.

Rozpatrując migracje w odniesieniu do liczby mieszkańców poszczególnych regionów, można było stwierdzić, że największą skalę wyjazdy osiągnęły w województwach: opolskim (2,4\% ludności), śląskim (1,0\%), dolnośląskim (0,7\%) i lubuskim $(0,6 \%)$. Najmniejszy natomiast ubytek ludności odnotowały województwa: mazowieckie $(0,1 \%)$, łódzkie $(0,2 \%)$, lubelskie $(0,2 \%)$ i świętokrzyskie $(0,2 \%)$.

Inną kwestią, bardzo ważną z punktu widzenia dalszego rozwoju gospodarki, jest to, kto emigruje z kraju. Dotyczy to głównie takich cech jak wiek oraz wykształcenie. Ponieważ to młodzi i wykształceni obywatele są potencjałem i motorem napędowym rozwoju ekonomicznego państwa. 


\begin{tabular}{|c|c|c|c|c|c|c|c|c|c|c|c|c|c|c|c|c|c|c|}
\hline \multirow{7}{*}{ 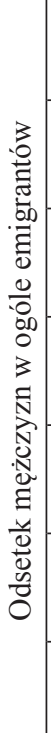 } & $\begin{array}{l}\stackrel{ }{\circ} \\
\stackrel{\sim}{N}\end{array}$ & $\hat{\sigma}$ & $\begin{array}{l}\dot{\forall} \\
\dot{f}\end{array}$ & $\overrightarrow{0}$ & $\vec{\infty}$ & F & $\stackrel{\infty}{\sim}$ & $\begin{array}{l}\infty \\
f \\
f\end{array}$ & $\left|\begin{array}{l}\infty \\
f^{*}\end{array}\right|$ & $\begin{array}{c}\vec{\sigma} \\
\infty \\
+\end{array}$ & $\left|\begin{array}{l}\infty \\
0 \\
f\end{array}\right|$ & $\begin{array}{l}\stackrel{\partial}{े} \\
\dot{f}\end{array}$ & $\begin{array}{l}\infty \\
\dot{f}\end{array}$ & $\begin{array}{l}r \\
6 \\
f\end{array} \mid$ & $\begin{array}{c}0 \\
\tilde{F}\end{array} \mid$ & $\begin{array}{l}\dot{t}_{\sigma} \\
\dot{f}^{\prime}\end{array}$ & $\stackrel{\circ}{\mathfrak{f}}$ & $\begin{array}{l}+ \\
\sigma \\
+\end{array}$ \\
\hline & ڤ્ণे & $\begin{array}{l}\tilde{y} \\
\tilde{\sigma}\end{array}$ & in & $\begin{array}{l}\dot{v}_{0} \\
\dot{f}\end{array}$ & 守 & $\begin{array}{l}\infty \\
\stackrel{n}{f}\end{array}$ & $\stackrel{\infty}{\stackrel{\infty}{\sim}}$ & हे & $\left|\begin{array}{c}0 \\
\tilde{F} \\
F\end{array}\right|$ & $\hat{\sigma}$ & $\begin{array}{l}n \\
\tilde{f}\end{array}$ & $\stackrel{\mathfrak{v}}{\stackrel{f}{*}}$ & $\vec{b}$ & $\begin{array}{l}\infty \\
\dot{f}\end{array}$ & $\begin{array}{l}\mathcal{Z} \\
f\end{array}$ & $\stackrel{\mathfrak{f}}{\mathfrak{f}}$ & $\vec{f}$ & $\begin{array}{l}0 \\
7\end{array}$ \\
\hline & 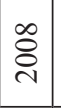 & $\begin{array}{l}0 \\
\tilde{n}\end{array}$ & $\hat{n}$ & $\begin{array}{l}m \\
n \\
n\end{array}$ & तิ & $\begin{array}{l}\text { से } \\
\text { in }\end{array}$ & $\begin{array}{l}n \\
0 \\
n \\
n\end{array}$ & $\begin{array}{c}n \\
n \\
n\end{array}$ & $\begin{array}{l}a \\
\tilde{n}\end{array}$ & $\begin{array}{l}\infty \\
\infty \\
i\end{array}$ & $\begin{array}{l}n \\
\tilde{n}^{2}\end{array}$ & $\hat{n}$ & $\begin{array}{l}\dot{\sigma}_{n} \\
\hat{n}\end{array}$ & $\begin{array}{l}0 \\
i n\end{array} \mid$ & च̃ & $\hat{n}$ & $\frac{\pi}{n}$ & $\hat{n}$ \\
\hline & 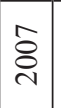 & $\begin{array}{l}\infty \\
\infty \\
\infty \\
n\end{array}$ & $\begin{array}{l}0 \\
\infty \\
\infty\end{array}$ & $\dot{\sigma}_{0}^{+}$ & in & $\hat{8}$ & $\frac{\pi}{6}$ & $\vec{n}$ & $\left|\begin{array}{l}\nabla \\
\infty \\
\infty\end{array}\right|$ & $\begin{array}{l}\vec{v} \\
i n\end{array}$ & $\left|\begin{array}{l}\infty \\
0 \\
0 \\
0\end{array}\right|$ & $\overrightarrow{8}$ & $\begin{array}{l}n \\
\infty \\
\infty\end{array}$ & $\begin{array}{l}\nabla \\
\tilde{n} \\
\tilde{n}\end{array}$ & $\begin{array}{l}n \\
2 \\
6\end{array}$ & $\begin{array}{l}\dot{ } \\
\infty \\
\infty\end{array}$ & $\overrightarrow{8}$ & $\begin{array}{l}0 \\
8 \\
0\end{array}$ \\
\hline & $\begin{array}{l}\text { ¿े } \\
\stackrel{\sim}{2}\end{array}$ & $\begin{array}{c}0 \\
\infty \\
i n\end{array}$ & $\begin{array}{l}n \\
\tilde{\delta}^{\prime} \\
n^{2}\end{array}$ & $\begin{array}{l}n \\
\tilde{n} \\
n\end{array}$ & $\hat{\jmath}$ & $\begin{array}{l}\hat{\partial} \\
\infty \\
n\end{array}$ & กิ & ñ & $\vec{n}$ & $\stackrel{m}{n}$ & $\begin{array}{l}0 \\
0\end{array}$ & $\begin{array}{l}\text { nీ} \\
\overbrace{}^{n}\end{array}$ & $\stackrel{a}{i n}$ & $\begin{array}{l}0 \\
0 \\
0 \\
n\end{array} \mid$ & $\hat{\sigma}$ & $\vec{\infty}$ & $\begin{array}{l}0 \\
8 \\
8\end{array}$ & $\begin{array}{l}n \\
\infty \\
\infty\end{array}$ \\
\hline & $\stackrel{\overbrace{}}{8}$ & $\begin{array}{l}\vec{r}_{0} \\
\stackrel{n}{n}\end{array}$ & $\begin{array}{c}0 \\
\infty \\
+\infty\end{array}$ & $\hat{\tilde{n}}$ & $\frac{N}{n}$ & ñ & $\begin{array}{l}0 \\
\dot{n}\end{array}$ & $\hat{n}$ & $\frac{n}{n}$ & $\begin{array}{l}\infty \\
\bullet \\
i \\
n\end{array}$ & $\begin{array}{l}\text { iे } \\
\dot{n}\end{array}$ & $\stackrel{\infty}{\stackrel{f}{f}}$ & $\begin{array}{c}n \\
i n\end{array}$ & $\begin{array}{l}0 \\
n \\
n\end{array} \mid$ & $\vec{m}$ & $\frac{0}{i n}$ & గ̌ & $\begin{array}{l}\dot{v} \\
\text { in }\end{array}$ \\
\hline & $\begin{array}{l}\text { ¿ } \\
\text { ¿ }\end{array}$ & $\frac{n}{n}$ & 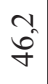 & $\stackrel{\infty}{\stackrel{f}{\gamma}}$ & $\Rightarrow$ & $\tilde{f}$ & $\frac{n}{f}$ & $\frac{\sigma_{n}}{i}$ & $\left|\begin{array}{c}1 \\
\infty \\
+\end{array}\right|$ & $\begin{array}{l}\vec{\infty} \\
\infty^{\prime}\end{array}$ & $\begin{array}{l}n \\
i \\
n\end{array}$ & के & $\begin{array}{l}0 \\
\tilde{n} \\
\text { n. }\end{array}$ & $\begin{array}{c}0 \\
\text { n } \\
\mid\end{array} \mid$ & $\begin{array}{c}\infty \\
\tilde{f} \\
\stackrel{f}{*}\end{array}$ & $\begin{array}{l}n \\
f \\
f\end{array}$ & $\begin{array}{l}\text { r. } \\
\text { fo }\end{array}$ & $\begin{array}{l}\infty \\
f \\
f\end{array}$ \\
\hline \multirow{7}{*}{ 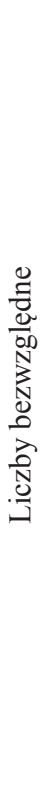 } & $\stackrel{\circ}{\stackrel{\circ}{\sim}}$ & $\frac{n}{a}$ & $\vec{\infty}$ & 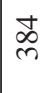 & $\vec{\sim}$ & $\stackrel{\widetilde{v}}{\widetilde{v}}$ & $\underset{\sim}{\circ}$ & రి & $\begin{array}{l}n \\
\tilde{d} \\
2\end{array}$ & ஓ & ষ্ণ & $\stackrel{\infty}{-1}$ & స్ర & $\begin{array}{l}0 \\
\infty \\
-1\end{array}$ & $\stackrel{\vec{m}}{=}$ & ॄे & $\stackrel{?}{\stackrel{9}{+}}$ & స్ర \\
\hline & ஓे & $\begin{array}{l}\vec{\nabla} \\
\infty\end{array}$ & $\frac{a}{a}$ & 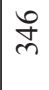 & $\vec{\sim}$ & $\stackrel{\circ}{\sim}$ & ֻे & ช్ & Әे & $\begin{array}{l}\infty \\
\infty \\
\infty\end{array}$ & 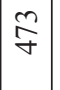 & $\stackrel{\infty}{\varrho}$ & $\underset{\substack{n \\
i n}}{0}$ & 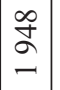 & $\exists$ & $\frac{n}{n}$ & ลี & m \\
\hline & 㐫 & $\begin{array}{l}\sqrt{6} \\
-1 \\
\underline{-1}\end{array}$ & $\frac{n}{2}$ & 每 & 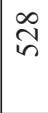 & $\stackrel{m}{n}$ & 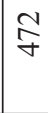 & 을 & $\frac{\infty}{6}$ & $\underset{\sim}{\stackrel{\Xi}{Z}}$ & $\begin{array}{l}\infty \\
0 \\
0\end{array}$ & nे & $\stackrel{\beth}{\beth}$ & $\left|\begin{array}{l}0 \\
0 \\
m \\
m\end{array}\right|$ & $\underset{\sim}{\stackrel{\Im}{+}}$ & すั & $\stackrel{\curvearrowright}{\infty}$ & $\bar{n}$ \\
\hline & $\hat{8}$ & $\begin{array}{l}+ \\
\infty \\
\stackrel{N}{N}\end{array}$ & $\begin{array}{l}\infty \\
\stackrel{\infty}{\sim}\end{array}$ & ga & $\vec{\infty}$ & 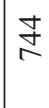 & రి & $\stackrel{m}{m}$ & 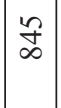 & $\begin{array}{c}\stackrel{\overbrace{}}{+} \\
\stackrel{+}{\sim}\end{array}$ & $\begin{array}{c}\mathbb{J} \\
\stackrel{\sim}{ } \\
-\end{array}$ & in & $\begin{array}{c}\tilde{n} \\
\sim\end{array}$ & 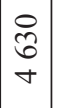 & $\frac{m}{\gamma}$ & $\stackrel{\circ}{a}$ & $\stackrel{n}{=}$ & ñ \\
\hline & ஓ̊ & $\begin{array}{l}\hat{n} \\
\hat{n}\end{array}$ & 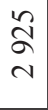 & m & $\begin{array}{l}\infty \\
\infty \\
0 \\
-\end{array}$ & $\underset{\infty}{\infty}$ & $\frac{ \pm}{\sigma}$ & $\begin{array}{l}n \\
\infty \\
\infty \\
-\end{array}$ & $\begin{array}{l}n \\
\stackrel{2}{2} \\
-\end{array}$ & $\underset{⿱ 亠}{\stackrel{\infty}{\sim}}$ & 훙 & $\hat{a}$ & $\begin{array}{l}\stackrel{\sim}{\sim} \\
\stackrel{\sim}{N}\end{array}$ & $\left|\begin{array}{l}2 \\
i n \\
n\end{array}\right|$ & $\widehat{0}$ & $\begin{array}{l}? \\
\stackrel{0}{0} \\
=\end{array}$ & $\frac{n}{m}$ & గુర \\
\hline & 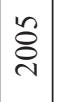 & $\begin{array}{l}\infty \\
\infty \\
= \\
=\end{array}$ & $\vec{\infty}$ & ô & $\infty$ & ले & $\stackrel{\curvearrowright}{\sim}$ & $\frac{2}{6}$ & $\stackrel{\circ}{\vec{\sim}}$ & 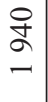 & $\frac{0}{6}$ & $\stackrel{尺}{\sim}$ & $\begin{array}{l} \pm \\
0 \\
-\end{array}$ & $\begin{array}{l}\hat{\sigma} \\
m \\
m\end{array}$ & 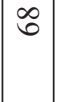 & $\hat{\infty}$ & $\hat{\sim}$ & $\hat{n}$ \\
\hline & 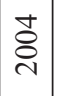 & $\begin{array}{l}\frac{0}{r} \\
a\end{array}$ & $\stackrel{8}{6}$ & $\stackrel{\circ}{\sim}$ & na & $\stackrel{\infty}{\infty}$ & $\stackrel{\Re}{ \pm}$ & 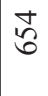 & 守 & $\begin{array}{l}\underset{\sim}{\sim} \\
\underset{\sim}{N}\end{array}$ & $\underset{\forall}{\Xi}$ & $\overrightarrow{\tilde{N}}$ & $\stackrel{2}{i n}$ & 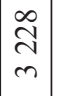 & 8 & $\frac{\ominus}{7}$ & $\infty$ & ๙ે \\
\hline$\frac{1}{2}$ & 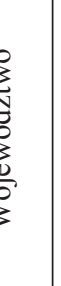 & $\begin{array}{l}\frac{\tilde{v}}{\tilde{v}} \\
0 \\
0\end{array}$ & 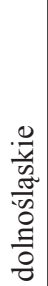 & 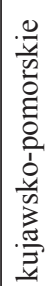 & \begin{tabular}{|} 
\\
.0 \\
$\frac{0}{0}$ \\
$\frac{0}{0}$ \\
$\frac{0}{0}$ \\
$\frac{0}{3}$
\end{tabular} & 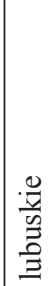 & $\frac{0}{\frac{0}{N}} \frac{1}{0}$ & 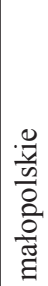 & 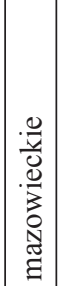 & $\begin{array}{l}\frac{0}{\frac{n}{n}} \\
\frac{0}{0} \\
\frac{a}{0}\end{array}$ & 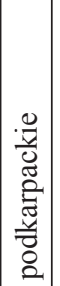 & 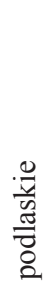 & 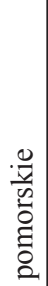 & 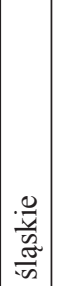 & 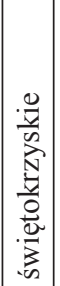 & 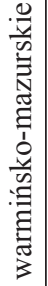 & $\begin{array}{l}\frac{0}{\frac{0}{0}} \\
\frac{a}{0} \\
\frac{0}{0} \\
\frac{0}{0} \\
\frac{0}{3}\end{array}$ & 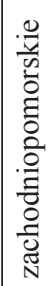 \\
\hline
\end{tabular}


Podczas analizy danych dotyczących tylko wyjazdów na pobyt stały okazało się, że mamy do czynienia $\mathrm{z}$ bardzo niekorzystnym trendem, ponieważ $\mathrm{w}$ badanym okresie niezmiennie największą grupę stanowiły osoby młode i bardzo młode. Sumaryczne dane z lat 2005-2010 wskazują na to, że w strukturze wyjazdów na pobyt stały dominowały osoby W wieku produkcyjnym (83\%), następnie przedprodukcyjnym (13\%), pozostałe 4\% stanowiły osoby w wieku poprodukcyjnym (tab. 2). Najwięcej osób młodych wyjechało z województw o największym odpływie migracyjnym (śląskiego, opolskiego i dolnośląskiego).

Tab. 2. Struktura wieku emigrantów na pobyt stały według województw (suma z lat 2005-2010)

\begin{tabular}{|l|r|r|r|r|r|r|}
\hline \multirow{2}{*}{ Województwo } & \multicolumn{2}{|c|}{ Liczby bezwzględne } & \multicolumn{3}{c|}{ Odsetek } \\
\cline { 2 - 7 } & $\begin{array}{c}\text { przed- } \\
\text { produkcyjny }\end{array}$ & $\begin{array}{c}\text { produk- } \\
\text { cyjny }\end{array}$ & $\begin{array}{c}\text { poproduk- } \\
\text { cyjny }\end{array}$ & $\begin{array}{c}\text { przed- } \\
\text { produkcyjny }\end{array}$ & $\begin{array}{c}\text { produk- } \\
\text { cyjny }\end{array}$ & $\begin{array}{c}\text { poproduk- } \\
\text { cyjny }\end{array}$ \\
\hline Polska & 22267 & 141681 & 6830 & 100,0 & 100,0 & 100,0 \\
\hline dolnośląskie & 2659 & 15069 & 494 & 11,9 & 10,6 & 7,2 \\
\hline kujawsko-pomorskie & 1123 & 6084 & 188 & 5,0 & 4,3 & 2,8 \\
\hline lubelskie & 588 & 4303 & 74 & 2,6 & 3,0 & 1,1 \\
\hline lubuskie & 957 & 4403 & 89 & 4,3 & 3,1 & 1,3 \\
\hline łódzkie & 657 & 4052 & 110 & 3,0 & 2,9 & 1,6 \\
\hline małopolskie & 1514 & 9717 & 321 & 6,8 & 6,9 & 4,7 \\
\hline mazowieckie & 796 & 5239 & 300 & 3,6 & 3,7 & 4,4 \\
\hline opolskie & 1113 & 16796 & 1432 & 9,5 & 11,9 & 21,0 \\
\hline podkarpackie & 619 & 8127 & 173 & 5,5 & 5,7 & 2,5 \\
\hline podlaskie & 1859 & 11012 & 417 & 8,3 & 7,8 & 6,1 \\
\hline pomorskie & 4421 & 33002 & 2559 & 19,9 & 23,3 & 37,5 \\
\hline śląskie & 394 & 2509 & 47 & 1,8 & 1,8 & 0,7 \\
\hline świętokrzyskie & 1160 & 6571 & 221 & 5,2 & 4,6 & 3,2 \\
\hline warmińsko-mazurskie & 1212 & 7123 & 184 & 5,4 & 5,0 & 2,7 \\
\hline wielkopolskie & 976 & 4264 & 128 & 4,4 & 3,0 & 1,9 \\
\hline zachodniopomorskie & & & & & & \\
\hline
\end{tabular}

Źródło: opracowanie własne na podstawie danych GUS

Z kolei dane dotyczące rodzaju wykształcenia emigrantów są mocno niedoszacowanie, ponieważ spora liczba osób nie podaje swojego wykształcenia w odpowiednich formularzach, najbardziej aktualne dane na ten temat pochodzą z 2005 roku.

Jeśli chodzi o poziom wykształcenia, wśród emigrantów dominują osoby z wykształceniem średnim, zasadniczym zawodowym, podstawowym (tab. 3). Niewątpliwym problemem jest jednak drenaż mózgów, który uwidacznia się w przypadku osób z wykształceniem wyższym. Odsetek emigrantów posiadających dyplom jest wyższy niż ich odsetek w społeczeństwie (ryc. 2). 


\begin{tabular}{|c|c|c|c|c|c|c|c|c|c|c|c|c|c|c|c|c|c|c|}
\hline \multirow{2}{*}{ 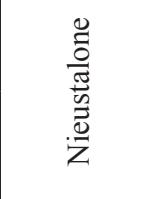 } & ஜ̊ & 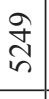 & $\vec{f}$ & $\underset{\Delta}{\Delta}$ & $\mathcal{f}$ & $\stackrel{\curvearrowright}{=}$ & $\approx$ & $\stackrel{\stackrel{\sim}{\sim}}{\sim}$ & $\stackrel{\infty}{=}$ & $\vec{\nabla}$ & $\stackrel{\infty}{=}$ & 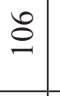 & $\tilde{ల}$ & $\begin{array}{l}\mathscr{\approx} \\
\infty \\
\infty\end{array}$ & $\ddot{\sim}$ & $\left|\begin{array}{l}0 \\
\infty \\
\infty\end{array}\right|$ & 守 & in \\
\hline & 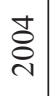 & $\stackrel{g}{\stackrel{0}{0}}$ & $\vec{\infty}$ & 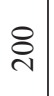 & $\approx$ & $\stackrel{n}{n}$ & $\mathbb{N}$ & $\overrightarrow{\text { ले }}$ & $\tilde{\sigma}$ & $\underset{\infty}{=}$ & $\overrightarrow{0}$ & $\cong$ & mे & $\begin{array}{l}\stackrel{J}{+} \\
\underset{N}{ }\end{array}$ & లి & $\mid \begin{array}{l}\infty \\
\stackrel{f}{q}\end{array}$ & $\hat{n}$ & $\hat{\tilde{\lambda}}$ \\
\hline \multirow{2}{*}{ 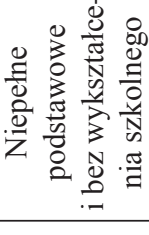 } & $\stackrel{2}{8}$ & 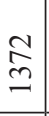 & $\hat{\beth}$ & 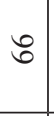 & $\cong$ & $\approx$ & ले & 2 & $\stackrel{\infty}{-}$ & in & $\infty$ & 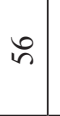 & 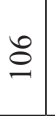 & $\stackrel{n}{m}$ & in & 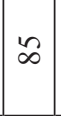 & $\hat{\sim}$ & $\hat{a}$ \\
\hline & ఫ্ণ & 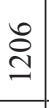 & $\vec{m}$ & $m$ & $\stackrel{+}{\sim}$ & P & $\stackrel{\infty}{\sim}$ & $\infty$ & $\vec{\sim}$ & $\stackrel{\infty}{\infty}$ & $\overrightarrow{6}$ & $\stackrel{0}{+}$ & $\infty$ & 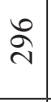 & $a$ & $\infty$ & $\widehat{\sim}$ & 8 \\
\hline \multirow{2}{*}{ 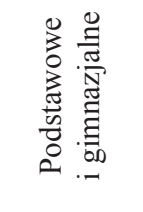 } & 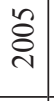 & $\underset{m}{\stackrel{F}{\sim}}$ & $\hat{\approx}$ & $\mathbb{N}$ & $\stackrel{\bullet}{\sim}$ & 2 & b & $\mathfrak{n}$ & $\ddot{m}$ & 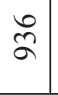 & $\stackrel{0}{0}$ & $\mathscr{\infty}$ & $\begin{array}{l}\stackrel{0}{\infty} \\
\stackrel{\sim}{\sim}\end{array}$ & $\stackrel{n}{\bumpeq}$ & 9 & $\stackrel{\circ}{\sim}$ & in & ิㅡ \\
\hline & $\begin{array}{l} \pm \\
\stackrel{\overbrace{}}{0}\end{array}$ & $\underset{n}{n}$ & 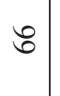 & $\tilde{\lambda}$ & $a$ & $\nabla$ & $\stackrel{0}{-}$ & N & $=$ & $\frac{ \pm}{m}$ & $\bar{\infty}$ & गे & $\vec{\sigma}$ & $\begin{array}{l}\infty \\
i n\end{array}$ & 0 & ก & $a$ & ஓి \\
\hline \multirow{2}{*}{ 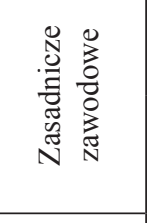 } & $\begin{array}{l}\stackrel{2}{0} \\
\stackrel{\overbrace{}}{2}\end{array}$ & 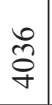 & $\stackrel{\infty}{\sim}$ & $\Xi$ & $\widehat{\imath}$ & $\hat{a}$ & $\vec{\nabla}$ & $\stackrel{0}{0}$ & \pm & $\Xi$ & $\stackrel{\infty}{0}$ & $\stackrel{\infty}{+}$ & ๙े & $\underset{\Xi}{ \pm}$ & 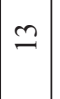 & $\stackrel{n}{m}$ & ర్ & ஃ \\
\hline & ষ্ঠ & $\stackrel{n}{\stackrel{n}{\sim}}$ & $\stackrel{+}{2}$ & $\widehat{6}$ & $\approx$ & $\tilde{n}$ & $\approx$ & 守 & $\cong$ & $\hat{n}$ & $\stackrel{ \pm}{\sim}$ & กี & $\stackrel{ \pm}{\sim}$ & 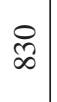 & $\vec{\sim}$ & $\tilde{a}$ & F & fo \\
\hline \multirow{2}{*}{ 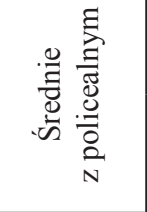 } & 空 & $\stackrel{\circ}{\circ}$ & $\vec{g}$ & $\stackrel{\infty}{-1}$ & 守 & $\vec{\Xi}$ & $\infty$ & 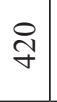 & $\infty$ & ลิ & ষ্ণ & $\stackrel{\vec{\lambda}}{\vec{v}}$ & $\begin{array}{l}\vec{\infty} \\
i n\end{array}$ & $\stackrel{\infty}{0}$ & in & $\stackrel{\sim}{~}$ & $\stackrel{\Xi}{2}$ & $\stackrel{\circ}{\stackrel{0}{\sim}}$ \\
\hline & ষ্ণ & 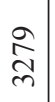 & 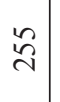 & $\mathscr{\infty}$ & 6 & ৪ & $\stackrel{\circ}{2}$ & $\vec{J}$ & $\stackrel{\infty}{\infty}$ & $\underset{+}{\stackrel{\infty}{+}}$ & సે & $\stackrel{m}{=}$ & $\widehat{\tilde{N}}$ & $\stackrel{\infty}{\infty}$ & + & $\stackrel{\circ}{\circ}$ & $\infty$ & $\hat{n}$ \\
\hline \multirow{2}{*}{ 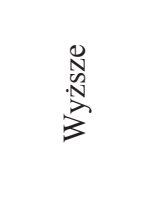 } & $\stackrel{\overbrace{}}{\stackrel{\sim}{2}}$ & $\begin{array}{l}0 \\
\infty \\
\infty \\
-\end{array}$ & $\stackrel{9}{I}$ & $n$ & $n$ & F & $\hat{0}$ & ષ્ণ & 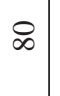 & 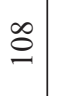 & $\stackrel{\infty}{\simeq}$ & $\stackrel{q}{q}$ & $\hat{\vartheta}$ & 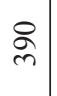 & I & in & 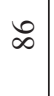 & $\stackrel{n}{r}$ \\
\hline & ষ্ণ & 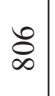 & $\approx$ & $\cong$ & $\stackrel{\infty}{=}$ & $\stackrel{\sim}{~}$ & छ & $\begin{array}{l}0 \\
\end{array}$ & से & $\hat{n}$ & $\stackrel{\sim}{\sim}$ & $\stackrel{\infty}{m}$ & 6 & $\stackrel{8}{ \pm}$ & $\because$ & 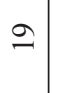 & $\forall$ & $n$ \\
\hline \multicolumn{2}{|l|}{$\begin{array}{l}0 \\
\frac{1}{10} \\
0 \\
0 \\
\frac{0}{0} \\
3 \\
3\end{array}$} & $\begin{array}{l}\frac{\tilde{v}}{\tilde{w}} \\
0 \\
\tilde{2}\end{array}$ & \begin{tabular}{|c|} 
\\
.0 \\
$\frac{0}{0}$ \\
$\frac{0}{0}$ \\
$\frac{0}{0}$ \\
0 \\
0 \\
0 \\
0
\end{tabular} & 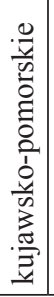 & $\begin{array}{l}\frac{0}{0} \\
\frac{v}{0} \\
0 \\
\frac{0}{3}\end{array}$ & $\begin{array}{l}\frac{.}{\tilde{z}} \\
\underline{0} \\
\underline{\Xi} \\
\end{array}$ & \begin{tabular}{|}
0 \\
$\frac{0}{3}$ \\
$\frac{0}{0}$ \\
\end{tabular} & 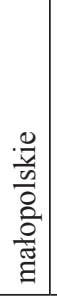 & 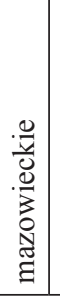 & \begin{tabular}{|l|}
$\frac{0}{\pi}$ \\
$\frac{a}{0}$ \\
0 \\
0 \\
0
\end{tabular} & 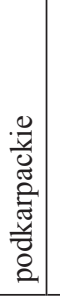 & $\begin{array}{l}\frac{0}{\pi} \\
\frac{\pi}{0} \\
\frac{\tilde{g}}{\tilde{z}} \\
0 \\
\end{array}$ & 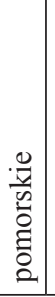 & 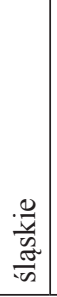 & 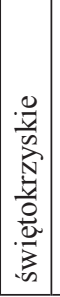 & 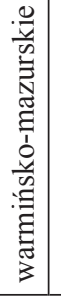 & $\begin{array}{l}\frac{0}{0} \\
\frac{7}{0} \\
0 \\
\frac{0}{2} \\
\frac{0}{0} \\
\frac{0}{3} \\
\end{array}$ & 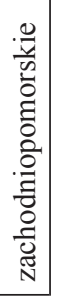 \\
\hline
\end{tabular}




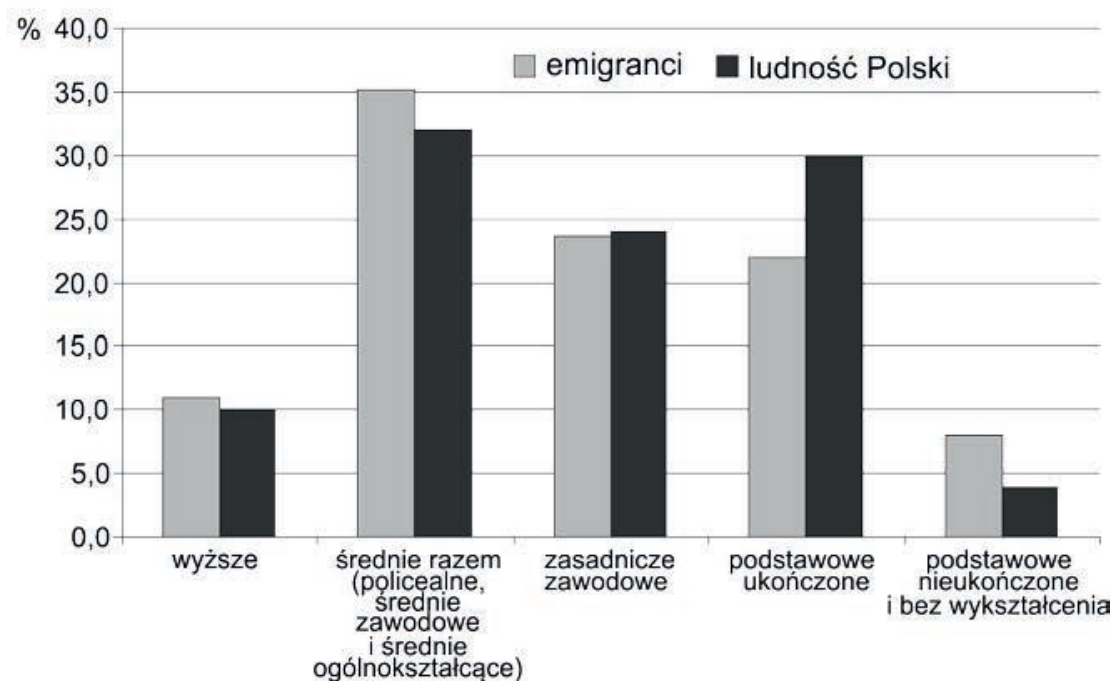

Ryc. 2. Struktura wykształcenia emigrantów i ludności Polski

Źródło: opracowanie własne na podstawie danych NSP 2002 i GUS

Łatwo jest również zauważyć dysproporcje związane z selektywnym odpływem wyspecjalizowanej kadry pracowniczej. Okazuje się bowiem, że osoby z wyższym wykształceniem stanowiły 35,6\% ogółu emigrantów w województwie mazowieckim, 26,3\% w lubelskim oraz 25,5\% w łódzkim. Dodatkowo wyniki badań przeprowadzonych w Londynie wskazują na to, że ponad połowa ankietowanych posiadała wyższe wykształcenie $(58,5 \%)$. Duży udział miały także osoby posiadające wykształcenie średnie $(33,9 \%)$, zasadnicze zawodowe $(6,7 \%)$. Osoby z najniższym poziomem wykształcenia (podstawowym) stanowiły zaś $0,9 \%$ ogółu ankietowanych.

Problem odpływu osób z wykształceniem wyższym dotyczył przede wszystkim trzech województw: mazowieckiego, małopolskiego i śląskiego, z których wyjechało najwięcej osób. Odnosząc się jednak do struktury wykształcenia emigrantów w układach lokalnych, stwierdzono, że drenaż mózgów dotyczył również regionów słabo rozwiniętych gospodarczo, czyli takich, które nie zapewniały osobom wykształconym odpowiednich miejsc pracy. Były to województwa: świętokrzyskie (70\%), lubuskie (66,7\%), śląskie (60\%) czy lubelskie (59,8\%) (tab. 4). 
Tab. 4. Struktura wykształcenia Polaków w Londynie według regionów pochodzenia w 2010 roku

\begin{tabular}{|l|r|r|r|r|c|}
\hline \multicolumn{1}{|c|}{ Województwo } & Ogółem & Wyższe & Średnie & $\begin{array}{c}\text { Podstawowe, } \\
\text { gimnazjalne, } \\
\text { zasadnicze } \\
\text { zawodowe }\end{array}$ & $\begin{array}{c}\text { Odsetek osób } \\
\text { z wykształceniem } \\
\text { wyższym w ogóle } \\
\text { ankietowanych }\end{array}$ \\
\hline dolnośląskie & 72 & 37 & 25 & 10 & 51,4 \\
\hline kujawsko-pomorskie & 52 & 30 & 16 & 6 & 57,7 \\
\hline lubelskie & 92 & 55 & 28 & 9 & 59,8 \\
\hline lubuskie & 15 & 10 & 4 & 1 & 66,7 \\
\hline łódzkie & 62 & 37 & 20 & 5 & 59,7 \\
\hline małopolskie & 116 & 68 & 37 & 11 & 58,6 \\
\hline mazowieckie & 138 & 103 & 30 & 5 & 74,6 \\
\hline opolskie & 19 & 9 & 7 & 3 & 47,4 \\
\hline podkarpackie & 86 & 48 & 36 & 2 & 55,8 \\
\hline podlaskie & 41 & 14 & 24 & 3 & 34,1 \\
\hline pomorskie & 84 & 41 & 32 & 11 & 48,8 \\
\hline śląskie & 105 & 63 & 39 & 3 & 60,0 \\
\hline świętokrzyskie & 30 & 21 & 7 & 2 & 70,0 \\
\hline warmińsko-mazurskie & 30 & 14 & 13 & 3 & 46,7 \\
\hline wielkopolskie & 56 & 29 & 23 & 4 & 51,8 \\
\hline zachodniopomorskie & 40 & 18 & 17 & 5 & 45,0 \\
\hline
\end{tabular}

Źródło: opracowanie własne na podstawie badań ankietowych

\section{Podsumowanie}

Reasumując, należy stwierdzić, że akcesja Polski do Unii Europejskiej spowodowała niekorzystny proces emigracji głównie młodych osób, które pochodziły przede wszystkim z terenów o słabym poziomie rozwoju ekonomicznego. Największym problemem jest drenaż mózgów, zwłaszcza z terenów peryferyjnych kraju, tzn. z województw: świętokrzyskiego, lubuskiego, lubelskiego oraz śląskiego. Prowadzi to nie tylko do depopulacji tych terenów, ale przede wszystkim do ubożenia jakości zasobów ludzkich w tych regionach. Należałoby zatem podjąć wysiłki zmierzające do zwiększenia liczby odpowiednich miejsc pracy dla młodych ludzi, zmianę skomplikowanych niekiedy przepisów prawnych, ułatwiających młodym osobom rozwój własnych przedsiębiorstw i w ten sposób zahamować niekorzystny proces emigracji klasy kreatywnej za granicę. Jest to istotne, gdyż badania pokazują, że zdecydowana większość młodych emigrantów nie zamierza wracać do kraju, a tylko nieliczni wykorzystują swój kapitał społeczny po powrocie do Polski (Gałka, 2012a). Tym samym Polska traci tysiące osób, które nie odnalazły się na lokalnych rynkach pracy. 


\section{Literatura}

Barteczko, A. (2006). Brain Drain or Brain Gain?, Warsaw Business Journal. Pozyskano z: http:// www.bankier.pl/wiadomosc/Brain-drain-or-brain-gain-1404788.html

Borowiec, M. (2008). Rola szkolnictwa wyższego w procesie kształtowania gospodarki opartej na wiedzy. Przedsiębiorczość - Edukacja, 4, 24-36.

Borowiec, M. (2010). Funkcjonowanie uczelni krakowskiego i rzeszowskiego ośrodka akademickiego w świetle koncepcji układów bipolarnych. Kraków: Wydawnictwo Naukowe Uniwersytetu Pedagogicznego.

Borowiec, M. (2011). Zmiany kierunków kształcenia akademickiego w Polsce. Prace Komisji Geografii Przemystu Polskiego Towarzystwa Geograficznego, 18, 9-22.

Borowiec. M., Dorocki. S. (2011). Rola kapitału ludzkiego w procesie kształtowania innowacyjności układów regionalnych Francji. W: B. Namyślak (red.), Przekształcenia regionalnych struktur funkcjonalno-przestrzennych. Wrocław: Uniwersytet Wrocławski, 215-228.

Borowiec, M., Dorocki, S., Jenner, B. (2009). Wpływ zasobów kapitału ludzkiego na kształtowanie społeczeństwa informacyjnego i innowacyjności struktur przemysłowych. Prace Komisji Geografii Przemystu Polskiego Towarzystwa Geograficznego, 13, 95-109.

Chojnicki, Z., Czyż T. (2008). Gospodarka oparta na wiedzy w regionach metropolitalnych i aglomeracjach miejskich w Polsce. Studia KPZK PAN, 120, 74-95.

Dorocki, S. (2008). Gospodarka oparta na wiedzy w założeniach Strategii Lizbońskiej - na przykładzie Francji. Przedsiębiorczość - Edukacja, 4, 183-191.

Dorocki S., Jastrzębski J. P. (2011). Regionalne zróżnicowanie rozwoju biotechnologii w Europie. W: Z. Zioło, T. Rachwał (red.), Problematyka 27. Międzynarodowej Konferencji Naukowej nt. Wplyw innowacyjności na rozwój przedsiębiorstw i gospodarki w układach przestrzennych. Kraków: Wydawnictwo Naukowe Uniwersytetu Pedagogicznego, 30-31.

Gałka, J. (2012a). Polacy w przestrzeni społecznej Londynu u progu XXI wieku. Praca doktorska niepublikowana, Kraków: IGiGP UJ.

Gałka, J. (2012b). Przestrzenne rozmieszczenie poakcesyjnych imigrantów z Polski w Wielkiej Brytanii wraz z analizą skali imigracji z Polski. Prace Geograficzne, 129, 7-22.

Goldberg, I. (2004). Poland and the Knowledge Economy. Enhancing Poland's Competitiveness in European Union. Pruszków: „Rewasz” Publishing House.

Goldberg, I., Goddard, G., Kuriakose, S. (2008). Building Knowledge Based Economies and Absorptive Capacity to Enhance Growth. W: M. Runiewicz-Wardyn (ed.), Knowledge Based Economy as a Factor of Competitiveness and Economic Growth. Warsaw: TIGER Publication, 11-24.

Glytsos, N.P. (2006). Is Brain Drain from Albania, Bulgaria and Greece Large Enough to Threaten Their Development? Reports and Analyses, 14 (06), 1-20.

Guastella, G., Oort van, F. (2012). Knowledge Creation vs Knowledge Co-Production:Knowledge Intensive Business Servises and Innovative Activity in EU Regions. ERSA Conference Papers Number ersa12p424, European Regional Science Association. Pozyskano z http://www-sre. wu.ac.at/ersa/ersaconfs/ ersa12/e120821aFina100426.pdf

Hryniewicz, J., Jałowiecki, B. , Mync, A. (1992). Ucieczka mózgów ze szkolnictwa wyższego i nauki. Raport z badań. Warszawa: Europejski Instytut Rozwoju Regionalnego i Lokalnego.

Hryniewicz, J., Jałowiecki, B., Mync, A. (1997). Ruchliwość pracowników naukowych w latach 19941997. Warszawa: Europejski Instytut Rozwoju Regionalnego i Lokalnego.

Ivakhnyuk, I. (2006). Brain Drain from Russia: In Search for a Solution. Reports and Analyses, 15 (06), 1-14. 
Kaczmarczyk, P. (2006). Highly Skilled Migration from Poland and Other CEE Countries - Myths and Reality. Reports and Analyses, 17 (06), 1-28.

Kaczmarczyk, P., Okólski, M. (2005). Migracje specjalistów wysokiej klasy w kontekście członkostwa w Unii Europejskiej. Warszawa: UKIE.

Kilar, W. (2008). Zatrudnienie w działalnści badawczej i rozwojowej jako czynnik rozwoju gospodarki opartej na wiedzy. Przedsiębiorczość - Edukacja, 4, 60-69.

Krupa, K. (2012). Narzędzia otwartej ekonomii - kapitał intelektualny, RTE oraz coaching (zarys wybranych poglądów i wyniki badań). Prace Komisji Geografii Przemystu Polskiego Towarzystwa Geograficznego, 19, 9-27.

Lee, E.S. (1966). A Theory of Migration. Demography, 3 (1), 47-57.

Mellander, Ch., Florida, R. (2012). The Rise of Skills: Human Capital, the Creative Class and Regional Development. CESIS Electronic Working Paper Series, 266. Pozyskano z: http://ideas.repec.or$\mathrm{g} / \mathrm{p} / \mathrm{hhs} / \mathrm{cesisp} / 0266 . \mathrm{html}$

Miyamoto, K. (2003). Human Capital Formation and Foreign Direct Investment in Developing Countries. OECD Development Centre Working Paper, 211.

Parkhomenko, N. (2006). Migration of Highly-qualified Professionals from Ukraine: Current Situation and Future Threats. Reports and Analyses, 18 (06), 1-7.

Pollard, N., Latorre, M., Sriskandarajah D. (2008). Floodgates or Turnstiles? Post-EU Enlargement Migration Flows to (and from) the UK. London: IPPR.

Rachwał, T. (2011). Industrial Restructuring in Poland and Other European Union States in the Era of Economic Globalization. Procedia Social and Behavioral Sciences, 19, 1-10.

Ravenstein, E.G. (1885). The Laws of Migration. Journal of the Statistical Society of London, 48 (2), $67-235$.

Rosner, A. (2009). Uwarunkowania społeczno-gospodarcze zwiazane z restrukturyzacja funkcji rolniczej wsi. Pozyskano z: http://www.mrr.gov.pl/rozwoj_regionalny/poziom krajowy/polska_polityka_przestrzenna/prace_nad_KPZK_2008_2033/Documents/Rosner.pdf

Stryjakiewicz, T. (2009). Lokalizacja firm i zachowania przestrzenne pracowników sektora informatycznego (na przykładzie poznańskiego obszaru metropolitalnego). Prace Komisji Geografii Przemystu Polskiego Towarzystwa Geograficznego, 13, 21-33.

Zioło, Z. (2008). Ekonomiczne i społeczne uwarunkowania rozwoju gospodarki opartej na wiedzy. Przedsiębiorczość - Edukacja, 4, 12-23.

Jadwiga Gałka, dr, Uniwersytet Jagielloński, Instytut Geografii i Gospodarki Przestrzennej.

Ukończyła studia geograficzne na Uniwersytecie Pedagogicznym w Krakowie oraz studia doktoranckie na Uniwersytecie Jagiellońskim. Obecnie pracuje jako asystent w Instytucie Geografii i Gospodarki Przestrzennej Uniwersytetu Jagiellońskiego. Jej zainteresowania badawcze koncentrują się wokół poakcesyjnych migracji Polaków, w tym głównie na badaniu przestrzennej i społecznej mobilności nowych polskich imigrantów w Londynie.

Jadwiga Gałka, graduated from the Pedagogical University of Cracow, MA degree in Geography, $\mathrm{PhD}$ in Geography (the Institute of Geography and Spatial Management of the Jagiellonian University). Assistant at the Institute of Geography and Spatial Management of the Jagiellonian University. Her research interests are tied with post-accession migration of Poles, focusing around spatial and social mobility of new Polish immigrants in London. 
Sławomir Dorocki, dr, Uniwersytet Pedagogiczny w Krakowie, Instytut Geografii, Zakład Przedsiębiorczości i Gospodarki Przestrzennej.

Absolwent studiów z zakresu geografii społeczno-ekonomicznej Uniwersytetu Pedagogicznego w Krakowie, doktor nauk humanistycznych w zakresie historii (Instytut Europeistyki - Uniwersytet Jagielloński). Adiunkt w Instytucie Geografii Uniwersytetu Pedagogicznego w Krakowie. Jego zainteresowania badawcze skupiają się wokół problematyki regionów i procesów regionalizacji społeczno-gospodarczej, ze szczególnym uwzględnieniem zróżnicowania przestrzeni europejskiej oraz procesów integracji europejskiej i uwarunkowań historycznych.

Sławomir Dorocki, graduated from Pedagogical University of Cracow, MA degree in Geography, $\mathrm{PhD}$ in History (the Institute of European Studies of the Jagiellonian University). Senior Lecturer at the Pedagogical University of Cracow, the Institute of Geography. His research interests are tied with regional problems and processes of socio-economic regionalization, with particular emphasis on the diversity of Europe, processes of European integration and historical conditions.

adres/address: Uniwersytet Pedagogiczny w Krakowie

Instytut Geografii

Zakład Przedsiębiorczości i Gospodarki Przestrzennej

ul. Podchorążych 2, 30-084 Kraków, Polska (Sławomir Dorocki)

Uniwersytet Jagielloński, Instytut Geografii i Gospodarki Przestrzennej

ul. Gronostajowa 7, 30-387 Kraków, Polska (Jadwiga Gałka)

e-mail: sdorocki@up.krakow.pl (Sławomir Dorocki),

jadwiga.galka@uj.edu.pl (Jadwiga Gałka) 